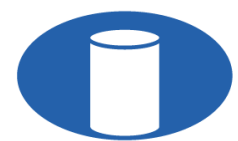

IBRACON Structures and Materials Journal

Revista IBRACON de Estruturas e Materiais

IBRACON

ISSN 1983-4195

ismj.org

ORIGINAL ARTICLE

\title{
Analysis of structural masonry buildings taking into account the construction sequence loads and soil-structure interaction
}

\section{Análise de edifícios de alvenaria estrutural considerando a sequência construtiva e a interação solo-estrutura}

Anna Christinna Secundo Lopes ${ }^{\mathrm{a}}$ (1)

Joel Araújo do Nascimento Neto ${ }^{\mathrm{a}}$ (D)

Rodrigo Barros ${ }^{\mathrm{a}}$ (1)

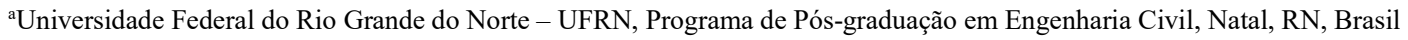

Received 26 October 2020

Accepted 03 March 2021

\begin{abstract}
The present study assesses conventionally used design standards, analyzing the effects caused by the construction loads, that is, a gradual increase in load and stiffness during construction, and soil-structure interaction (SSI), with soil represented by linear springs, in a structural masonry building over a support structure of reinforced concrete. The equivalent frame model, developed by Nascimento Neto, was used to simulate the support structure and the first masonry floor, and a specific three-dimensional frame model to simulate the other floors. Four analysis models were applied to assess stress distribution at the base of the walls, and the stresses and displacements of the support structure. The results show that introducing SSI and the construction loads causes relief or the possible need to reinforce elements designed in Ultimate Limit State (ULS) and Serviceability Limit State (SLS), as well as uniform settlement.
\end{abstract}

Keywords: structural masonry, reinforced concrete support structure, soil-structure interaction, construction sequence loads.

\begin{abstract}
Resumo: O presente estudo realiza uma avaliação crítica de critérios de projeto convencionalmente utilizados, consistindo em uma análise dos efeitos causados pela sequência construtiva, ou seja, incremento gradativo de carregamento e rigidez dos elementos com a evolução da construção, e pela interação solo-estrutura (ISE), representando o solo por molas lineares, em um edifício de alvenaria estrutural sobre estrutura de transição em concreto armado. Foi utilizado o modelo de barras equivalentes, desenvolvido por Nascimento Neto, para discretização da estrutura de transição e do primeiro pavimento em alvenaria, e o modelo de pórtico tridimensional específico para discretização dos demais pavimentos. Mediante quatro modelos de análises, foram avaliadas as distribuições das tensões na base das paredes, e os esforços e deslocamentos da estrutura de transição. Os resultados evidenciam que a introdução da ISE e do efeito construtivo provocam alívio ou possível necessidade de reforço em elementos dimensionados no Estado Limite Último (ELU) e no Estado Limite de Serviço (ELS), assim como uniformização de recalques.
\end{abstract}

Palavras-chave: alvenaria estrutural, estrutura de transição em concreto armado, interação solo-estrutura, efeito construtivo.

How to cite: A. C. S. Lopes, J. A. Nascimento Neto, and R. Barros, "Analysis of structural masonry buildings taking into account the construction sequence loads and soil-structure interaction," Rev. IBRACON Estrut. Mater., vol. 14, no. 6, e14607, 2021, https://doi.org/10.1590/S198341952021000600007

\section{INTRODUCTION}

The use of structural masonry buildings has been increasing due to the proven optimization of materials and labor, thereby reducing costs. For this reason, tall buildings have been constructed with structural masonry in some regions

Corresponding author: Anna Christinna Secundo Lopes. E-mail: annasecundolopes@gmail.com

Financial support: The author gratefully acknowledges the support of the Civil Engineering Graduate Program of the Federal University of Rio Grande do Norte. This paper was financed in part by the Coordenação de Aperfeiçoamento de Aessoal de Nível superior (CAPES) - Financing Code 001.

Conflict of interest: Nothing to declare. 
of Brazil. However, simultaneously to this development, there is a need to improve research and technologies and increase the use of structural masonry to the levels of reinforced concrete.

The most widely used methods, which are conservative and out-of-date, do not fully exploit the potential of masonry. From the standpoint of analytical research, the interaction between structural masonry walls and reinforced concrete support structures - whether in first floors or foundations - deserves mention, since the arch effect may lead to incorrect design when incorrectly interpreted or overly large cross sections properties of concrete structural elements when ignored.

Item 11.5 of Brazilian Standard Code NBR 16055 [1] makes it mandatory to analyze soil-structure interaction (SSI) in buildings constructed with concrete walls and more than five floors high. In the case of Brazilian standard NBR 16868-1 [2], concerning structural masonry buildings, there is no mention of the need to incorporate soil-structure interaction in analyses, but recent studies, such as those by Testoni [3] and Santos [4], report that soil interaction provokes significantly changes in the stress flow in walls, thereby producing more realistic results.

In addition to the effects of SSI, it is important to underscore that the structure may be submitted to considerably different stress levels from those of conventional analysis, which considers the instantaneous action of total loading in the structure. Structural analysis considering the construction effects, and, as such, closer to reality, is relevant in the study of stress distribution in walls, and to evaluate the shear forces and bending moments in support structures and SSI effects.

Thus, the present study arises from the need for further research on structural masonry, to assess the consequences of soil-structure interaction, considering the progressive effects of construction.

Given the aspects described, the primary aim was to investigate the effects caused by the deformability of support structures and analyze the progressive sequence and increased stiffness associated with the construction stages of buildings. This research, therefore, hopes to contribute with a critical assessment of the conventional analysis method, which considers the hypothesis of total load acting instantaneously and fully-fixed foundation supports.

\section{THEORETICAL FRAMEWORK}

\subsection{Interaction of wall-beam systems}

According to Barbosa [5], a structural masonry wall can be supported by continuous strip footings, or by discontinuous arrangement conditions associated to the columns position in a frame structure or to pile foundation. In the first case, vertical loads are distributed nearly uniformly at the base of the wall, while in the second, the loads tend to be directed towards the supports, since they are the stiffest regions, raising the stress concentration in these areas. This phenomenon is designated wall-beam system or the so-called arch effect, as illustrated in Figure 1, which changes stress distribution at the base of the wall and shear forces and bending moments on the support beam.

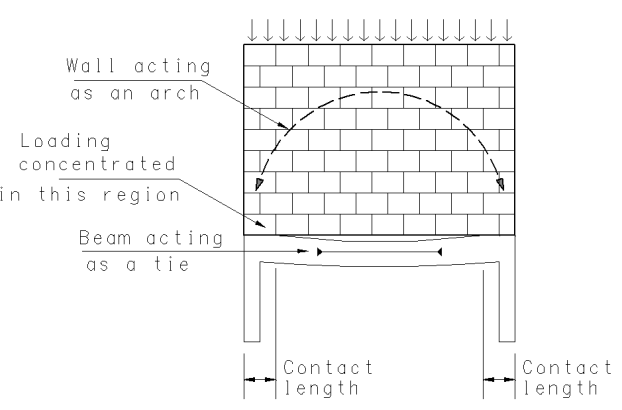

Figure 1. Continuous action of the wall-beam system. Adapted from Barbosa [5].

Normal vertical tensile stress may occur at the wall-beam interface, which can cause the two elements to separate when maximum joint tensile strength is reached. The possible loss of contact intensifies the load transfer to the supports, as reported by Barbosa [5]. Transferring loads to the supports concentrates vertical compression and horizontal shear stress at the base of the wall. 


\subsection{Computational modeling}

Computational modeling based on the finite element method (FEM) is currently used in studies on support structures. A new computational model able to consistently simulate wall-beam interaction was developed by Nascimento et al. [6], corresponding to a set of vertical and horizontal bars denominated equivalent frame model (EqFM). The authors established the efficiency of the model by comparing their results with those obtained by shell finite element modeling.

Medeiros [7] confirmed the new equivalent frame model by studying different generic walls, comparing the results with the Rosenhaupt experimental model, and the three-dimensional frame modeling of a number of walls of a real building design. The results showed the efficiency of the modeling proposed, which consisted of wall discretization by a set of vertical and horizontal bars spaced $15 \mathrm{~cm}$ and $20 \mathrm{~cm}$ apart, respectively (Figure 2). This disposition of the bars was selected after a consistent mesh study comparing the results with those obtained by similar discretization in shell finite elements. Due to the orthotropic nature of structural masonry, especially when using hollow concrete blocks, it is recommended that longitudinal and transverse elasticity modulus be adopted for horizontal bars with half the value used for vertical bars, as reported by Parsekian et al. [8]. An exception for this assumption is the section of horizontal bars with grouting, usually related to lintel blocks. In relation to the connection between the EqFM and support beams, it is necessary to adopt bars with pinned end in the connection to the beam.

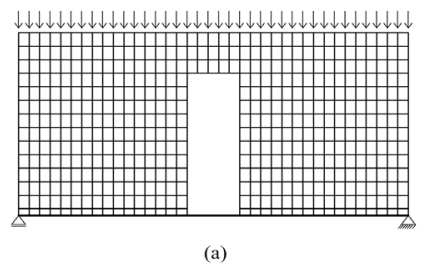

(a)

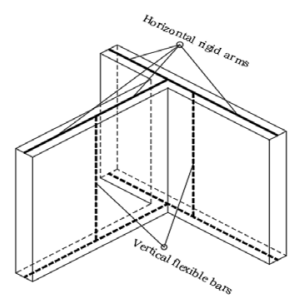

(b)

Figure 2. Numerical modeling: (a) Equivalent frame model (EqFM); (b) Three-dimensional frame model (TFM).

Lopes [9] made adjustments in the model ratified by Medeiros [7], including fitting the areas and stiffnesses established for the bars. The author assessed different models that considered the properties of the bars in terms of gross and net sections, concluding that adopting gross sections with elastic properties produces satisfactory results. Thus, it is reasonable to adopt the elastic properties of masonry grouted to the section of the masonry that contains vertical grouting, and the elastic properties of ungrouted masonry to the section without grouting, both with respect to the gross area of the bar section.

Nascimento [10] used the three-dimensional frame model (Figure 2b) to study the effects of shear strain and global torsion of building on shear walls of structural masonry buildings subjected to wind loads. The model consisted of shear walls discretized by three-dimensional frame elements, which had six degrees of freedom at each end. These frames exhibited the same geometric properties as the respective walls that they represented, and was positioned at the center of gravity of the rectangular section of the wall. The walls that intercept one another were connected by rigid horizontal bars (rigid arms), the ends being common to the two adjacent walls. The ends of the flexible vertical bars were continuously connected to the rigid horizontal counterparts, which, in turn, were arranged at the level of the floors. Their purpose was to simulate the effect of the length of the walls and the interaction between them. The length and number of rigid arms in the modeling depends on the intersections between these walls and the inclusion or not of lintels. Slab modeling was designed as a rigid diaphragm in its plane, in order to simulate displacement at the floor level. These displacements were associated with the two independent translation movements in the plane of the floor and rotation around the normal axis to this plane.

The two aforementioned models were used simultaneously in the analyses conducted, whose details are described in the following items.

\subsection{Soil-structure interaction}

In general, building design consider the simplified hypothesis in which foundations are joined to the built structure through fixed supports. Modeling best fit the physical reality, considering soil deformability, which is denominated soil-structure interaction (SSI). Several studies have demonstrated that adopting elastic supports (deformable soil 
hypothesis) using SSI leads to stresses different from those calculated considering a foundation over fixed supports (rigid soil hypothesis), according to Gusmão and Gusmão [11], Prado [12] and Testoni [3].

Dutta and Roy [13] provided an extensive review of literature to gather the possible alternative models available for SSI, with emphasis to the physical modeling of the soil media. According to authors, studies seeking model to represent soil behavior result in two classical models: Winkler's model and continuous model. Winkler's model is the oldest and the simplest one and can be defined as a set of linear, discrete, independent, closely spaced springs, in which the deformation of foundation due to applied load is confined to loaded regions only. As the formulation of this model depends only the linear spring stiffness, it is classified as one parameter discrete model. Over the years some researchers developed studies to improve the Winkler's model, such as Filonenko-Borodich [14], Hetenyi [15], Pasternak [16], Kerr [17], Horvath [18] and Kurian and Manojkumar [19]. All these studies were developed with the main objective to consider continuity among springs, extending the deformation of foundation beyond the regions of applied loads.

For deep foundations, the use of discrete models indicates that the response of the soil at a certain point does not depend on pile displacement at different points. Thus, soil response consists of independent discrete mechanisms, which does not perfectly characterize the continuous method. When simulating soil with a discrete spring model, the corresponding stiffness is represented by the coefficient of vertical reaction $k_{v}$, defined by Terzaghi [20] as the ratio between pressure acting on the contact surface and vertical displacement due to the applied load. This coefficient can be obtained by plate tests, typical values in correlation to SPT tests, and correlations to settlement and foundation geometry. When deep foundations are subjected to horizontal actions, the Winkler model approach is non-linear elastic. Hence the use of $\mathrm{p}-\mathrm{y}$ curves is an excellent alternative to represent this behaviour. The geotechnical parameter that feeds the model is the coefficient of horizontal reaction $k_{h}$, which can be obtained by a load test on the pile in a natural scale, plate tests developed by Terzaghi [20] in 1955, or through empirical correlations with other soil properties. According to Araújo [21], concerning piles subjected to horizontal forces numerous studies have been made, such as: Matlock and Reese [22], Broms [23], Alizadeh and Davisson [24], Poulos [25], Cintra [26], Miguel [27], Del Pino [28], Fan and Long [29]; and Zammataro [30].

The coefficient of horizontal reaction of the soil $\left(k_{h}\right)$ is also interpreted as a pile-soil horizontal contact stiffness. According to Terzaghi [20] this coefficient is calculated by dividing the stress $\left(p_{r}\right)$ by the corresponding horizontal displacement $(y)$, Equation 1. A more comprehensive explanation for the coefficient of horizontal reaction of the soil is based on distributed load $(p)$ over the pile length instead of horizontal normal stress $\left(p_{r}\right)$. This consideration establishes the definition of the modulus of horizontal reaction of the soil $(K)$. The $K$ value is calculated by dividing the soil reaction, or distributed load over the pile length, by the horizontal displacement $(y)$, Equation 2. Considering that $p$ is calculated multiplying $p_{r}$ by the pile diameter $(B)$, the Equation 3 is obtained, which expresses the correlation between the coefficient of horizontal reaction and the modulus of horizontal reaction of the soil.

$k_{h}=\frac{p_{r}}{y}$

$$
K=\frac{p}{y}
$$

$$
K=k_{h} \cdot B
$$

The determination of $K$ value is too complex due to its variation with depth, and due to the difficulty to obtain an experimental value. For most of the researchers, the $\mathrm{K}$ value is constant for pre-consolidated clay and obeys a linear function for sand, according to Cintra [26]. Hence, Equation 4 expresses the $K$ values for sand, in which $n_{h}$ denotes the constant of horizontal reaction of the soil, and $Z$ denotes the depth.

$$
K=n_{h} \cdot Z
$$

The $n_{h}$ values obtained using Araujo's [21] load test results were used in this research. Lopes [31] describes in detail and indicates all the parameters used in this research to calculate the coefficients $k_{h}$ and $n_{h}$. 


\subsection{Construction sequence loads}

Analysis of structures conventionally considers the final effect of loads and concrete with reference age for the specified $\mathrm{f}_{\mathrm{ck}}$ (concrete characteristic compressive strength). However, analyses considering the construction stages, that is, the evolution of loads and corresponding age of the concrete, tend to produce different results. In addition, the removal of shoring and consequent load applied to early-age elements demonstrates the importance of verifying not only the Ultimate Limit State (ULS), but also the Serviceability Limit States (SLS), which can be considerably influenced by early-age cracking and deformation of elements.

Santos [4] used DIANA ${ }^{\circledR}$ software to confirm Prado's results [12]. The author found that the vertical reactions in columns tend to be smaller in sequential analysis, while in relation to the normal stresses on masonry, analysis of the construction effect showed a significant influence only on the first floor.

According to Gusmão and Gusmão [11], during the construction process, the increase in structure stiffness as the floors are being built produces a trend to settlement uniformization.

The variation in the mechanical properties of concrete with age is prescribed in NBR 6118 [32], according to the evolution of compression strength, up to 28 days. With respect to masonry, unlike concrete structures, the variation in mechanical properties with age can be disregarded, depending on the analysis. Parsekian and Franco [33] conducted threeblock prism tests for various ages with concrete and ceramic blocks, and found that for ages up to three days, prisms exhibit nearly characteristic compressive strength. It is important to underscore that this trend is associated with the use of fabricated structural blocks more than 28 days old. Thus, resistance values as a function of the variation in age are influenced only by mortar, which, in turn, if adequately specified, may not significantly influence prism behavior.

\section{MODELS ADOPTED IN ANALYSES}

All the computational models were developed with the SAP2000 structural analysis program, version 14.0.0. The first masonry floor and the support structure in reinforced concrete were discretized using the previously described equivalent frame model (EqFM). The other floors of the building were discretized with the three-dimensional-frame model. This procedure was adopted to reduce the computational effort and model processing time, given that the EqFM, exhibited far more unknowns than the three-dimensional frame model.

For the EqFM adopted for the first floor, the optimal mesh proposed by Medeiros [7] was used, as previously described. Discretization consisted of arranging the vertical and horizontal bars spaced 15 and $20 \mathrm{~cm}$ apart, with cross-sections measuring (14 x 15) $\mathrm{cm}^{2}$ and $(14 \times 20) \mathrm{cm}^{2}$, respectively. All the masonry walls had 14 courses (2.80m) consisting of M15 modulation blocks (14x29x19) $\mathrm{cm}^{3}$ containing bonding beams at the upper course, lintels and sills. For support structure beams, $15 \mathrm{~cm}$-long bar elements were used for each stretch, as well as the cross-section depth indicated in the original structural design. The first floor is $3.2 \mathrm{~m}$ high, which was therefore the height of the support structure columns. The first and second floors were connected using the same rigid bar of the three-dimensional frame model. This rigid bar was connected to the last course of the EqFM by additional vertical bars pinned at the base, as illustrated in Figure 3.

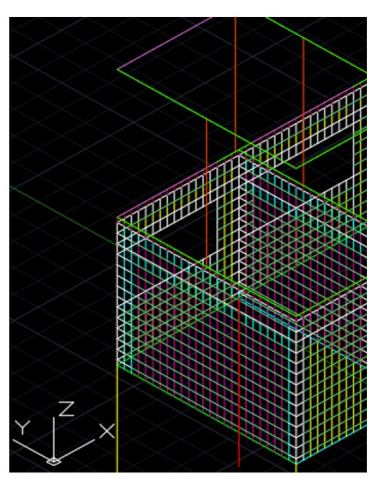

(a)

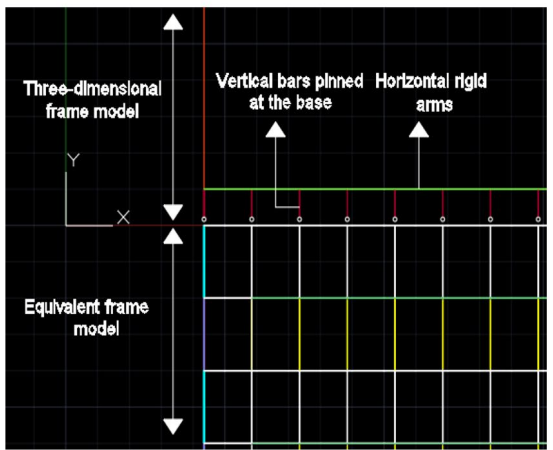

(b)

Figure 3. Connection between the equivalent frame and three-dimensional frame model: (a) General overview of first, second and third floors; (b) Connection details.

For concrete support structure and first floor of the structural masonry, the longitudinal and transverse elasticity modulus of concrete and masonry were determined based on Brazilian Standard Codes NBR 6118 [32] 
and NBR 16868-1 [2], for a concrete with $\mathrm{f}_{\mathrm{ck}}=25 \mathrm{MPa}$ and concrete blocks with $\mathrm{f}_{\mathrm{bk}}=22 \mathrm{MPa}$. Moreover, a relationship between characteristic compressive strength of the prism and block $\left(\mathrm{f}_{\mathrm{pk}} / \mathrm{f}_{\mathrm{bk}}\right)$ of $65 \%$ and a relationship between the resistance of the grouted and hollow prisms of 1.85 were adopted. The Brazilian Standard Code for masonry structures NBR 16868-1 [2] establishes the calculation of the longitudinal elasticity modulus, via the following equations:

$$
\begin{aligned}
& E_{\text {masonry }}=800 \cdot f_{p k}\left(\text { for } f_{b k} \leq 16 \mathrm{MPa}\right) \\
& E_{\text {masonry }}=650 \cdot f_{p k}\left(\text { for } f_{b k}>16 \mathrm{MPa}\right)
\end{aligned}
$$

When following the NBR 6118 [32], item 15.7.3, for non-linear analysis of global second order effects, the approximate physical non-linearity caused by cracking must be considered, to reduce structural element stiffness according to Equation 3 for beams and Equation 4 for columns and shear-walls:

$$
\begin{aligned}
& (E \cdot I)_{s e c}=0,4 \cdot E_{c i} \cdot I_{c}\left(\text { for } \dot{A}_{s}^{\prime} \neq A_{s}\right) \\
& (E \cdot I)_{\sec }=0,8 \cdot E_{c i} \cdot I_{c}\left(\text { for } A_{s}^{\prime}=A_{s}\right)
\end{aligned}
$$

Where: $E_{c i}$ denotes the tangent/initial elasticity longitudinal modulus of concrete; $I_{c}$ denotes the cross-section moment of inertia; $A_{s}^{\prime}$ denotes the cross-section reinforcement acting in compression; and $A_{s}$ denotes the cross-section reinforcement acting in tension.

Table 1 summarizes the material properties for the reinforced concrete support structure and the first masonry floor.

Table 1. Properties of the materials: equivalent frame model.

\begin{tabular}{cccc}
\hline \multirow{2}{*}{ Material } & \multirow{2}{*}{ Specific weight $\left(\mathbf{k N} / \mathbf{m}^{\mathbf{3}}\right)$} & \multicolumn{2}{c}{ Elasticity Modulus (MPa) } \\
\cline { 3 - 4 } & & Longitudinal & Transverse \\
\hline Concrete (beams) & 25 & 9660 & 4025 \\
\hline Concrete (columns) & 25 & 19320 & 8050 \\
\hline Non-grouted masonry & 14 & 9295 & 4648 \\
\hline Grouted masonry & 22 & 17196 & 8598 \\
\hline
\end{tabular}

For the other masonry floors, discretized with the three-dimensional frame model described by Nascimento [10], the longitudinal elasticity modulus followed the evolution of $\mathrm{f}_{\mathrm{pk}}$ values for each floor in establishing the flexible bars properties, as presented in Table 2 . In the case of lintels, the same properties as grouted masonry from the $1^{\text {st }}$ floor were attributed.

Table 2. Longitudinal modulus of elasticity of flexible bars per floor.

\begin{tabular}{cccccc}
\hline Floor & $\mathbf{f}_{\mathbf{p k}}(\mathbf{M P a})$ & $\begin{array}{c}\text { Modulus of } \\
\text { elasticity } \mathbf{E}_{\mathbf{m}} \mathbf{( M P a )}\end{array}$ & Floor & $\mathbf{f}_{\mathbf{p k}} \mathbf{( M P a )}$ & $\begin{array}{c}\text { Modulus of } \\
\text { elasticity E } \mathbf{m}(\mathbf{M P a})\end{array}$ \\
\hline 1 & 14.3 & 7436 & 11 & 9.1 & 5824 \\
\hline 2 & 14.3 & 7436 & 12 & 9.1 & 5824 \\
\hline 3 & 14.3 & 7436 & 13 & 7.5 & 4800 \\
\hline 4 & 13.0 & 6760 & 14 & 7.5 & 4800 \\
\hline 5 & 13.0 & 6760 & 15 & 8.0 & 5120 \\
\hline 6 & 13.0 & 6760 & 16 & 8.0 & 5120 \\
\hline 7 & 11.7 & 6084 & 17 & 6.4 & 4096 \\
\hline 8 & 11.7 & 6084 & 19 & 6.4 & 4096 \\
\hline 9 & 10.4 & 6656 & 4.8 & 3072 \\
\hline 10 & 10.4 & 6656 & 20 & 4.8 & 3072 \\
\hline
\end{tabular}


Four analysis models were developed:

- Model 1: usual design model, considering columns with a fully-fixed base and applying total loads instantaneously; it is important to underscore that, in this research, this model was considered the reference not for being the best established model, but because it is commonly used in building design;

- Model 2: considered the SSI with vertical and horizontal springs, and applying total loads instantaneously;

- Model 3: considered columns with a fully-fixed base, and applying the construction sequence loads;

- Model 4: considered the SSI with vertical and horizontal springs, and applying the construction sequence loads.

Conventional analyses consider the linear elastic behavior of materials. However, sequential analyses with construction stages are non-linear, and the behavior of concrete follows normative specifications. The models with construction stages used a specific routine of non-linear analysis of the SAP2000. In this routine, each loading stage is associated with the construction of a new floor (including foundations, when discretized). When a floor is introduced, there are only the lower floors in the numerical model. Hence, the accumulated stresses/strains, at this moment, are not influenced by the upper floors. This procedure characterizes a nonlinear analysis because a state of stress/strain in the structure is previously present. Moreover, if any horizontal displacement occurs, the software routine makes corrections on the upper floor displacements, leading to the initial/original position.

For models with construction stages, was defined a construction time of 7 days for each masonry floor. The mechanical properties of the reinforced concrete structure were changed every week, up to 28 days. Therefore, the floor loads were introduced, and the structure total vertical load increased at each floor incorporation.

The computational models included the wind loads calculated according to Brazilian Standard Code NBR 6123 [34], and considering the high of the building at the end of construction. In analyses of results were used the loading combinations for Ultimate Limit State prescribed by Brazilian Standard Code NBR 6118 [32].

This study used probing and lateral load testing data obtained by Araújo [21] at a building site in the city of Natal, Rio Grande do Norte state (RN), Brazil. Table 3 shows the coefficients of vertical reaction, calculated for piles $(10 \mathrm{~m}$ long and $60 \mathrm{~cm}$ in diameter) designed to support a axial force in columns between $1500 \mathrm{kN}$ and $2100 \mathrm{kN}$. The Cintra and Aoki [35] method was used to calculate settlement. The Aoki-Velloso [36] method was used to calculate lateral resistance for each $1 \mathrm{~m}$ section of the pile stem (with a contact area equal to the diameter of the foundation multiplied by the $1 \mathrm{~m}$ section of influence), and tip resistance (with a contact area of $\pi \mathrm{D}^{2} / 4$ ). Thus, the coefficients of vertical reaction were obtained by dividing the respective total resistances by the foundation settlement.

Table 3. Coefficients of vertical reaction of the soil.

\begin{tabular}{|c|c|c|c|c|c|c|c|c|c|}
\hline 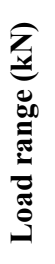 & 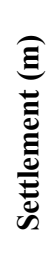 & 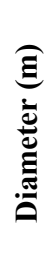 & 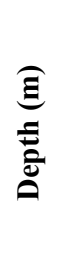 & 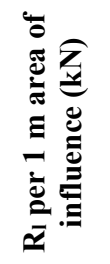 & 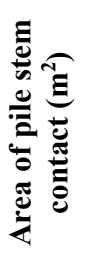 & ks stem $(\mathbf{k N} / \mathbf{m})$ & $\underbrace{\underset{z}{2}}_{\approx=}$ & 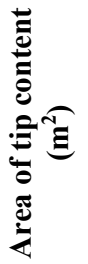 & 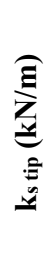 \\
\hline \multirow{10}{*}{ 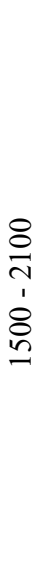 } & \multirow{10}{*}{$\begin{array}{l}0 \\
0 \\
0 \\
0 \\
0\end{array}$} & \multirow{10}{*}{$\stackrel{0}{0}$} & 1 & 13.2 & \multirow{10}{*}{$\begin{array}{l}0 \\
0\end{array}$} & 821.61 & \multirow{10}{*}{ 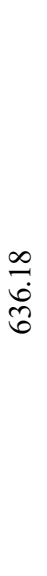 } & \multirow{10}{*}{$\stackrel{\infty}{\underset{0}{0}}$} & \multirow{10}{*}{ 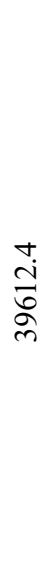 } \\
\hline & & & 2 & 29.69 & & 1848.69 & & & \\
\hline & & & 3 & 16.5 & & 1027.09 & & & \\
\hline & & & 4 & 29.69 & & 1848.69 & & & \\
\hline & & & 5 & 39.59 & & 2464.82 & & & \\
\hline & & & 6 & 101.79 & & 6338.11 & & & \\
\hline & & & 7 & 80.58 & & 5017.43 & & & \\
\hline & & & 8 & 59.38 & & 3697.07 & & & \\
\hline & & & 9 & 50.9 & & 3169.05 & & & \\
\hline & & & 10 & 63.62 & & 3961.08 & & & \\
\hline
\end{tabular}


A value of $n_{h}=37.2 \mathrm{MN} / \mathrm{m}^{3}$ was applied for the averaged continuous helix pile (CHP $\left.\mathrm{Cveraged}_{\text {A }}\right)$ related to displacement of $9 \mathrm{~mm}$, since it was the average value of the respective soil. Moreover, the fit proposed by Araújo [21] for Décourt's [37] equation was used, obtaining a new constant for the local soil. Araújo [21] explains in detail the initial value of $n_{h}$ and the Equation 10.

$\left(n_{h}\right)_{\text {Décourt }[37]}=1,6 \cdot N_{S P T}$

$\left(n_{h}\right)_{\text {Araijo }[21]}=2,65 \cdot N_{S P T}$

In preliminary studies with planar models, Lopes [31] obtained low values for the settlements. The author also identified that the usual iterative procedure to update the coefficients of vertical reaction, and stiffnesses of the springs, didn't produce a large variation in these values. Structural masonry buildings usually exhibit greater stiffness than concrete buildings, which can justify this tendency for ISS. Hence, the tridimensional modeling for SSI uses the initial stiffnesses of the springs only.

Table 4 shows the coefficients of horizontal reaction, calculated for piles ( $10 \mathrm{~m}$ long and $60 \mathrm{~cm}$ in diameter) designed to support a axial force in columns between $1500 \mathrm{kN}$ and $2100 \mathrm{kN}$. The value of the modulus of horizontal reaction $(\mathrm{K})$ was obtained by multiplying the value of $\mathrm{n}_{\mathrm{h}}$ by depth $\mathrm{z}$; then dividing by the pile diameter was obtained the coefficient of horizontal reaction $\left(\mathrm{k}_{\mathrm{h}}\right)$; and finally, multiplying by the contact area was obtained the spring stiffness $\left(\mathrm{k}_{\text {spring }}\right.$ ). The contact area was obtained by multiplying the diameter of the foundation by the $1 \mathrm{~m}$ length of influence.

Table 4. Coefficients of horizontal reaction of the soil.

\begin{tabular}{|c|c|c|c|c|c|c|c|c|c|}
\hline 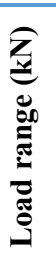 & 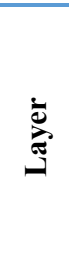 & NSPT & 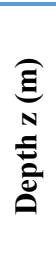 & $n_{h}\left(k N / m^{3}\right)$ & $K\left(\mathrm{kN} / \mathrm{m}^{2}\right)$ & 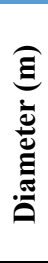 & $k_{h}\left(k N / m^{3}\right)$ & 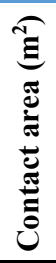 & $\mathbf{k}_{\text {spring }}(\mathrm{kN} / \mathrm{m})$ \\
\hline \multirow{11}{*}{$\begin{array}{l}8 \\
\stackrel{1}{1} \\
1 \\
\stackrel{8}{8} \\
\stackrel{2}{2}\end{array}$} & Top & - & - & 37200 & 37200 & \multirow{11}{*}{$\stackrel{0}{0}$} & 62000 & \multirow{11}{*}{$\stackrel{0}{0}$} & 37200 \\
\hline & 1 & 4 & 1 & 10600 & 10600 & & 17666.67 & & 10600 \\
\hline & 2 & 9 & 2 & 23850 & 47700 & & 79500 & & 47700 \\
\hline & 3 & 5 & 3 & 13250 & 39750 & & 66250 & & 39750 \\
\hline & 4 & 9 & 4 & 23850 & 95400 & & 159000 & & 95400 \\
\hline & 5 & 12 & 5 & 31800 & 159000 & & 265000 & & 159000 \\
\hline & 6 & 24 & 6 & 63600 & 381600 & & 636000 & & 381600 \\
\hline & 7 & 19 & 7 & 50350 & 352450 & & 587416.67 & & 352450 \\
\hline & 8 & 14 & 8 & 37100 & 296800 & & 494666.67 & & 296800 \\
\hline & 9 & 12 & 9 & 31800 & 286200 & & 477000 & & 286200 \\
\hline & 10 & 15 & 10 & 39750 & 397500 & & 662500 & & 397500 \\
\hline
\end{tabular}

The design of the continuous helix-type foundation piles was based on the support reactions obtained by the classical reference model (rigid supports and instantaneous loads). To that end, the normal forces on the columns, and consequent foundation loads, were placed within a range of values to reduce the variation in pile design. Therefore, the geometry of piles, and the corresponding coefficients of vertical and horizontal reactions, were obtained. From these coefficients, the stiffnesses of the corresponding springs were calculated. The ranges for the values of normal forces on columns were specified as follows: $1500 \mathrm{kN}$ up to $2100 \mathrm{kN} ; 2500 \mathrm{kN}$ up to $3100 \mathrm{kN} ; 4500 \mathrm{kN}$ up to $5800 \mathrm{kN}$; and $17900 \mathrm{kN}$ as the total axial force for a specific pile cap with seven columns, as shown in Figure 6b. Table 3 and Table 4 show the results for the first range only. 
After the stiffness values were calculated, the linear springs were introduced into their respective nodes via the corresponding coefficients in the $\mathrm{kN} / \mathrm{m}$ unit. Using $1 \mathrm{~m}$ soil layers, the horizontal springs were considered from the top of the pile, with vertical springs arranged in the middle of each layer, as shown in Figure 4.

The Aoki-Velloso [36] method was considered to calculate load-bearing capacity, the Cintra and Aoki [35] method to calculate settlements, and the Blévot and Frémy [38] method to determine pile cap geometry. It is important to underscore that the scope of the study is restricted to structural analysis and, as such, the design of these elements was not investigated in depth.

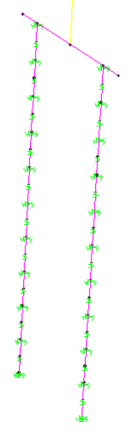

(a)

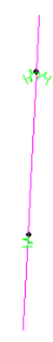

(b)

Figure 4. Soil-structure interaction: (a) 3D view of a block on two piles; (b) Horizontal and vertical springs applied at the nodes.

Figure 5 to Figure 7 show the layout of the reinforced concrete support structure, the masonry first course (highlighting the walls used in analysis), the foundation details, and the building discretization.

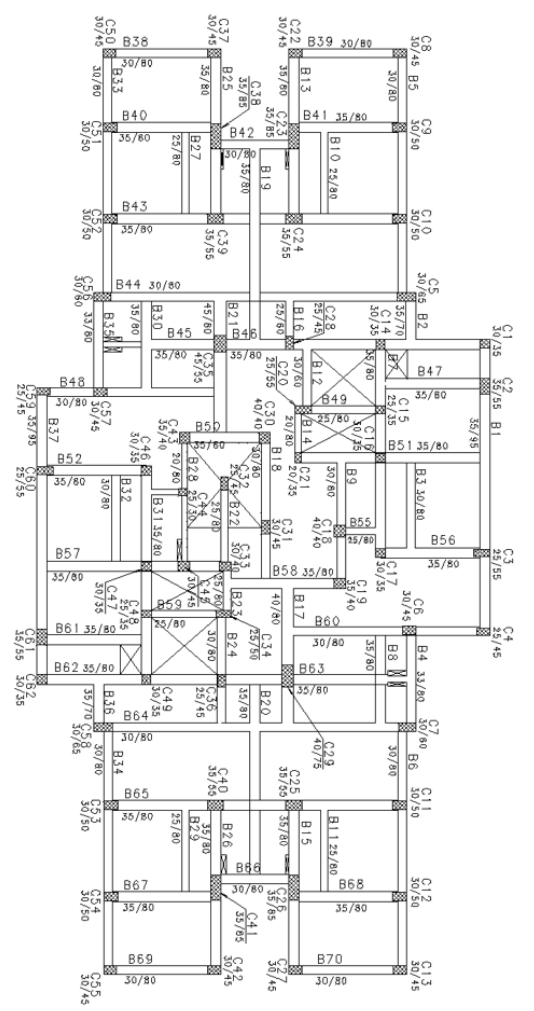

(a)

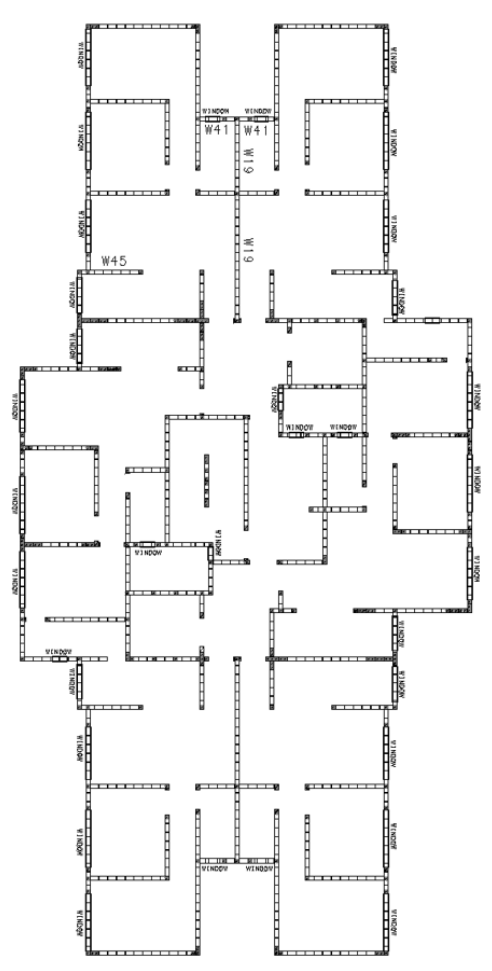

(b)

Figure 5. Building structure: (a) Reinforced concrete support structure; (b) Structural masonry first course. 


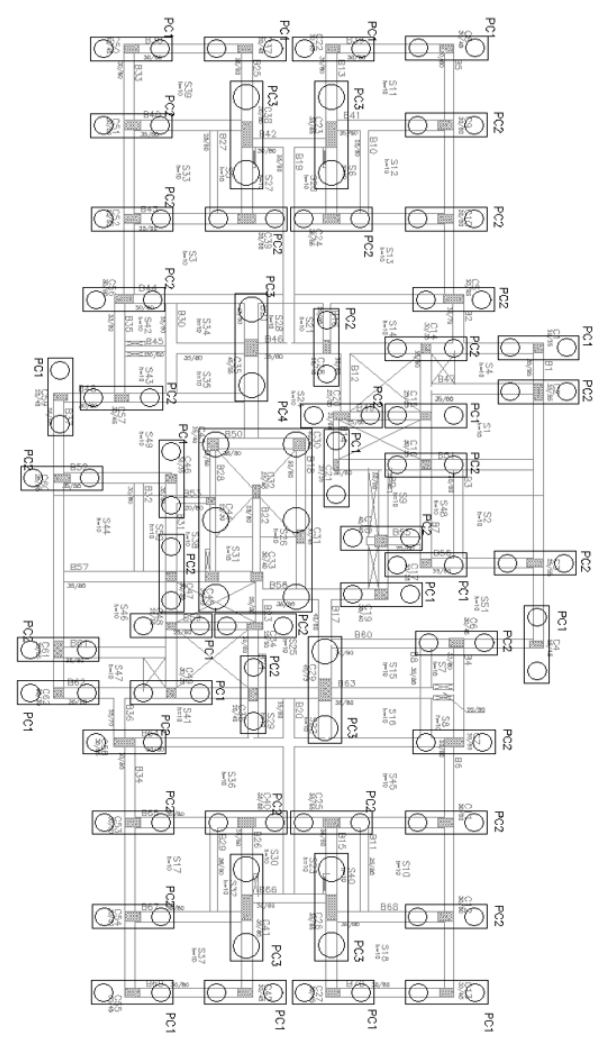

(a)
Pile cap dimensions: $260 \times 80 \times 100(\mathrm{~cm})$

Load range: 1500 a $2100 \mathrm{kN}$

Foundation: 2 Piles, $d=60 \mathrm{~cm} L=10$

Load range: $2100 ; 2500 \mathrm{kN}$

Foundation: 2 Piles, $d=60 \mathrm{~cm} \mathrm{~L} L=12 \mathrm{~m}$

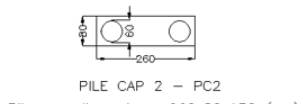

Pile cap dimensions: $260 \times 80 \times 130(\mathrm{~cm})$

Load range: 2500 a $3100 \mathrm{kN}$

Foundation: 2 Piles, $d=60 \mathrm{~cm} L=15 \mathrm{~m}$

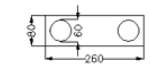

PILE CAP $3-$ PC3

Pile cap dimensions: $360 \times 105 \times 200(\mathrm{~cm})$

Load range: 4500 a $5800 \mathrm{kN}$

Foundation: 2 Piles, $d=85 \mathrm{~cm} \quad L=15 \mathrm{~m}$

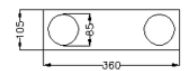

PILE CAP $4-$ PC4

Pile cap dimensions: $615 \times 360 \times 300(\mathrm{~cm}$

Lood: 17900

Foundation: 6 Piles, $d=85 \mathrm{~cm} L=15 \mathrm{~m}$

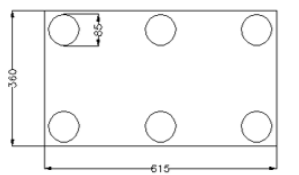

(b)

Figure 6. Foundations: (a) Floor plan; (b) Pile caps grouping by load ranges.

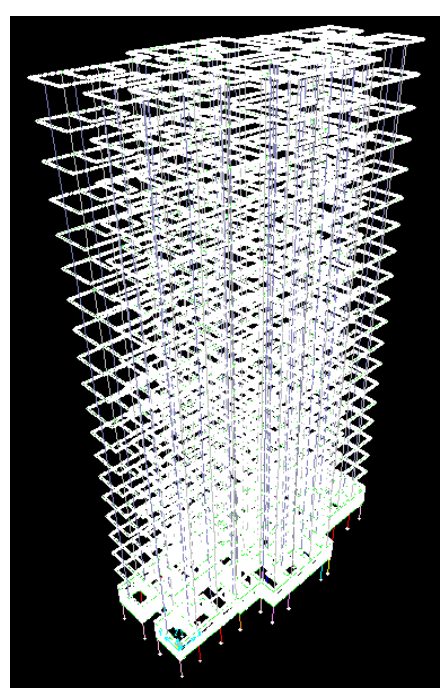

Figure 7. Building discretized in SAP2000 (fully-fixed base - model 1).

For purposes of assessing the results, the same subjective interpretation adopted by Testoni [3] and Santos [4] was used, based on NBR 8681 [39]. According to Santos [4], with coefficient $\Upsilon_{\mathrm{f}}$ for normal combinations of 1.4 and adopting $\Upsilon_{\mathrm{f} 1}=\Upsilon_{\mathrm{f} 3}$, it results that $\Upsilon_{\mathrm{f} 3}$ is the square root of $\Upsilon_{\mathrm{f}}$, assessed at 1.18. Based on these findings, it is assumed that variations up to $18 \%$ are covered by the safety factors (SF) of the design standards, corresponding to the deficiencies of the calculation method applied. For purposes of qualitative analysis, the same variation ranges for the differences used by Santos [4] were applied, as depicted in Table 5. 
Table 5. Ranges of the differences for the classical reference model.

\begin{tabular}{cc}
\hline Range & Quality of the difference \\
\hline$-5 \% \leq \mathrm{DIF} \leq 5 \%$ & Good/excellent \\
\hline $5 \%<\mathrm{DIF} \leq 18 \%$ or $-18 \% \leq \mathrm{DIF}<-5 \%$ & Fair \\
\hline $\mathrm{DIF}<-18 \%$ or $\mathrm{DIF}>18 \%$ & Poor/very poor \\
\hline
\end{tabular}

\section{RESULTS AND DISCUSSION}

Two walls from the building were selected for analyses: walls 41 and 45 , illustrated in Figure 8 . As a criterion, in addition to the vertical loads in the walls, the type of support and the existence of different openings were also considered. Thus, wall 41 contains two window openings and wall 45 has one end coincident with a column of the support beam and the other in an intermediate section of this beam, which, in turn, exhibits a relatively large span for this type of structure.

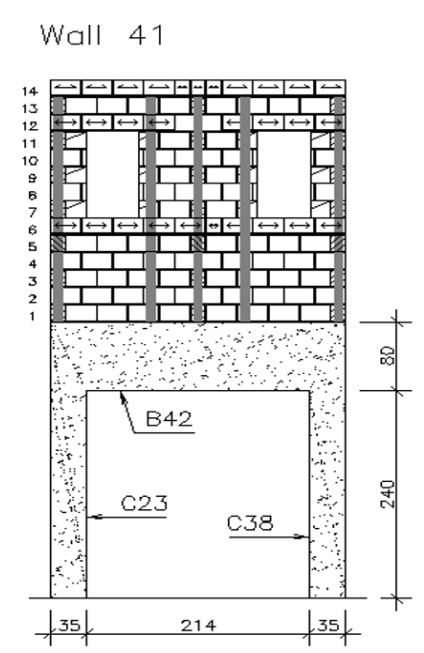

(a)

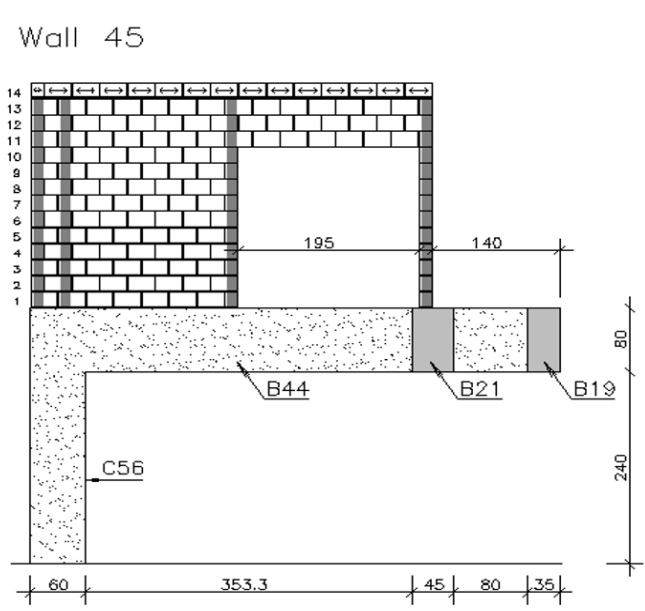

(b)

Figure 8. Wall's elevations: (a) Wall 41; (b) Wall 45.

\subsection{Results of wall 41}

Figure 9 illustrates the distribution of stresses at the base of wall 41, and Table 6 indicate their values in the regions of the end of support beam. The stress distribution indicated greater variations between the analysis models. The curves in Figure 9(a) and values presented in Table 6 demonstrate that for this wall, the normal stresses of model 2 in relation to model 1 were higher in the two peak regions and central region. Introducing the construction effect into the analyses caused a redistribution of stresses, thereby reducing normal stresses in the central region, despite continuing to display higher values at the ends. It is important to underscore that SSI in combination with the construction effect in model 4 intensified peak stress even more at the ends. With respect to these results, it is worth mentioning the results of wall 19 , which exhibited low normal stress intensity at the intersection with wall 41. Lopes [31] shows all results of the research. Since this intersection is a support point for the support beam, higher-intensity peaks were expected, which did not occur. Thus, the likely peaks at the end of wall 19 were redistributed to the two ends of wall 41 and intensified when the construction effect and SSI were considered. The vertical interfaces at the connection can withstand the shear stresses; otherwise, the redistribution cannot occur, completely changing the stresses on the walls and the forces on the support beams. 


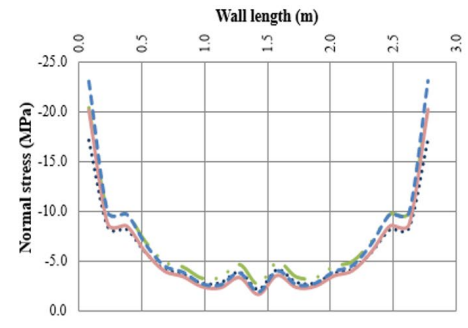

(a)

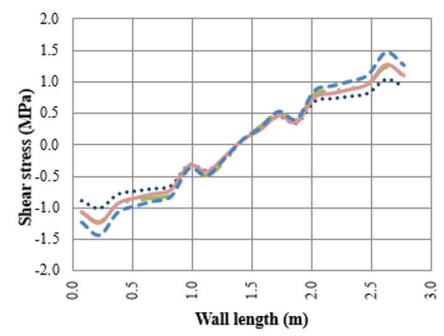

(b)

..... Model 1 - Fixed support Model 2 - SSI vert thoriz Model 3 - SC - - -Model 4 - SSI vert thoriz +SC

Figure 9. Distribution of stresses at the base of wall 41: (a) Normal stresses; (b) Shear stresses.

Table 6. Maximum values of normal and shear stresses of wall 41 .

\begin{tabular}{|c|c|c|c|c|c|c|c|c|}
\hline \multirow[b]{2}{*}{ Model } & \multicolumn{4}{|c|}{ Normal stress (MPa) } & \multicolumn{4}{|c|}{ Shear stress (MPa) } \\
\hline & Region P38 & $\begin{array}{c}\Delta \text { fixed } \\
\text { support }\end{array}$ & Region P23 & $\begin{array}{c}\Delta \text { fixed } \\
\text { support }\end{array}$ & Region P38 & $\begin{array}{c}\Delta \text { fixed } \\
\text { support }\end{array}$ & Region P23 & $\begin{array}{c}\Delta \text { fixed } \\
\text { support }\end{array}$ \\
\hline Model 1 & -17.07 & - & -17.18 & - & -1.01 & - & 1.04 & - \\
\hline Model 2 & -20.42 & $20 \%$ & -20.49 & $19 \%$ & -1.22 & $21 \%$ & 1.24 & $20 \%$ \\
\hline Model 3 & -20.15 & $18 \%$ & -20.23 & $18 \%$ & -1.25 & $23 \%$ & 1.27 & $22 \%$ \\
\hline Model 4 & -23.08 & $35 \%$ & -23.13 & $35 \%$ & -1.44 & $42 \%$ & 1.46 & $40 \%$ \\
\hline
\end{tabular}

Regarding shear stresses, at the two ends, models 2, 3 and 4 exhibit greater intensities than in model 1 . The differences are high, the highest being those associated with model 4, as shown in Table 6 .

Figure 10 illustrates the forces on the support beam of wall 41, and Table 7 contains the maximum intensities obtained. The axial force on the beam exhibited high differences between the models, where models 2, 3 and 4 resulted in tensile forces alone and at higher intensity than in model 1 - which has a short portion submitted to compression forces, albeit at low intensity, on the right-hand support. When compared to model 1, all the values varied beyond the SF.

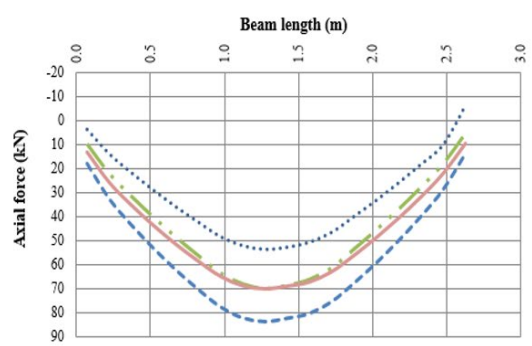

(a)

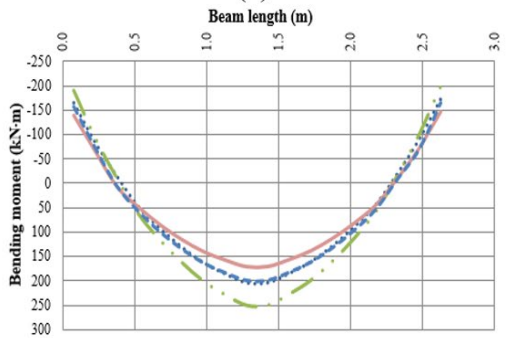

(c)

..... Model 1 - Fixed support Model 2 - SSI vert+horiz

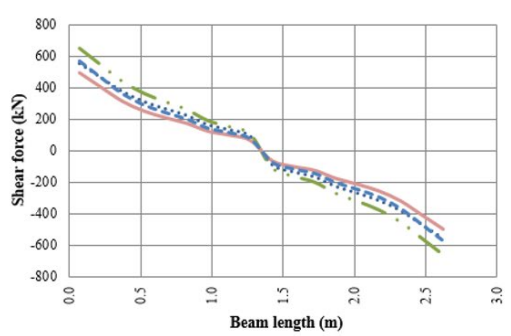

(b)

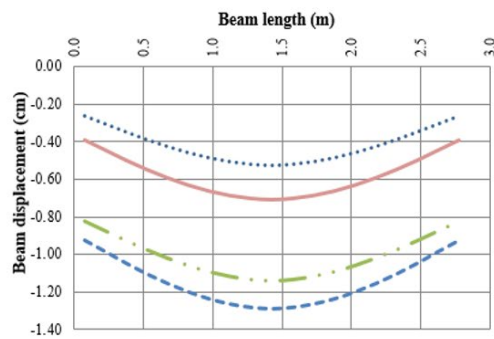

(d)

Model 3 - SC

- - -Model 4 - SSI vert thoriz + SC

Figure 10. Forces on the support beam of wall 41: (a) Axial force; (b) Shear force; (c) Bending moment; (d) Displacements. 
Table 7. Maximum forces on the support beam of wall 41 .

\begin{tabular}{|c|c|c|c|c|c|c|c|c|}
\hline \multirow[b]{2}{*}{ Model } & \multicolumn{2}{|c|}{ Axial Force (kN) } & \multicolumn{2}{|c|}{ Shear force $(k N)$} & \multicolumn{2}{|c|}{ Bending moment $(\mathrm{kN} \cdot \mathrm{m})$} & \multicolumn{2}{|c|}{ Displacements (cm) } \\
\hline & Maximum & $\begin{array}{c}\Delta \text { fixed } \\
\text { support }\end{array}$ & Maximum & $\begin{array}{c}\Delta \text { fixed } \\
\text { support }\end{array}$ & Maximum & $\begin{array}{c}\Delta \text { fixed } \\
\text { support }\end{array}$ & Maximum & $\begin{array}{c}\Delta \text { fixed } \\
\text { support }\end{array}$ \\
\hline Model 1 & 53.48 & - & 556.19 & - & 204.82 & - & 0.52 & - \\
\hline Model 2 & 70.01 & $31 \%$ & 659.17 & $19 \%$ & 249.37 & $22 \%$ & 1.14 & $118 \%$ \\
\hline Model 3 & 69.82 & $31 \%$ & 500.00 & $-10 \%$ & 169.78 & $-17 \%$ & 0.71 & $36 \%$ \\
\hline Model 4 & 83.65 & $56 \%$ & 572.41 & $3 \%$ & 199.57 & $-3 \%$ & 1.29 & $147 \%$ \\
\hline
\end{tabular}

In cases of shear force, the model 2 displays higher shear force and bending moment, which are mitigated when the construction stages in models 3 and 4 are considered. Moreover, displacements show high percentage differences, primarily when one considers interaction with the soil, reaching the normative limit of SLS $(1.0 \mathrm{~cm})$, when strain associated with the corresponding supports is disregarded.

\subsection{Results of wall 45}

The distribution of normal and shear stresses at the base of wall 45 are illustrated in Figure 11. In this case, the four models behaved similarly, with peaks occurring only at the left end, where column P56 is located, and slight variations along the entire length of the wall. It is important to underscore that the stress-free portion corresponds to that of the beam with no vertical load from structural masonry, and that the diagrams are represented until slightly to the right of the support provided by beam V44 on beam V19. With respect to the intensity of normal and shear stress peaks, considering the construction stages and the SSI resulted in considerable increases, even exceeding the limits of the SF, like what occurred in wall 41 , according to Table 8 . This wall shows the same typology as wall 25 , with one of the ends on the support of beam V22 and the other on the span of this beam. The difference refers to the higher support beam stiffness of wall 25 which, in addition to exhibiting a shorter span, has established supports in columns at both ends. This produced normal and shear stresses low peaks at the base of wall 25 in the span of beam V22, which did not occur in wall 45.

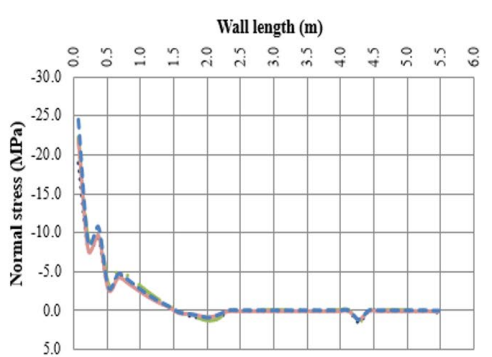

(a)

..... Model 1 - Fixed support

- Model 2 - SSI vert thoriz

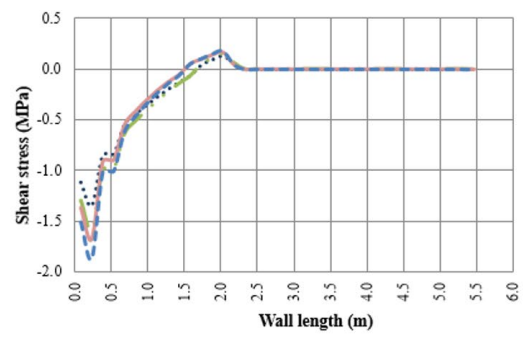

(b)

Model 3 - SC

-- Model 4 - SSI vert thoriz + SC

Figure 11. Distribution of stresses at the base of wall 45: (a) Normal stresses; (b) Shear stresses.

Table 8. Maximum values of normal and shear stresses of wall 45.

\begin{tabular}{ccccccc}
\hline \multirow{2}{*}{ Model } & \multicolumn{2}{c}{ Normal stress (MPa) } & & \multicolumn{2}{c}{ Shear stress (MPa) } \\
\cline { 2 - 3 } \cline { 5 - 6 } & Region P56 & $\Delta$ fixed support & & Region P56 & $\Delta$ fixed support \\
\hline Model 1 & -18.91 & - & $18 \%$ & & -1.35 & $18 \%$ \\
\hline Model 2 & -22.31 & $16 \%$ & & -1.59 & $24 \%$ \\
\hline Model 3 & -21.94 & $30 \%$ & & -1.67 & 3.86 & $38 \%$ \\
\hline Model 4 & -24.55 & & & & $3 \%$ \\
\hline
\end{tabular}


In terms of the forces on the support beam illustrated in Figure 12 and Table 9, axial force showed a decline in compression and rise in tension when considering the SSI and the construction stages in models 2,3 and 4, with the latter considering the simultaneous effects, resulting in a greater difference than in model 1 . With respect to shear forces, bending moments and displacements, the same aspects described in previous walls are repeated as follows: considering only the SSI is the most unfavorable situation, with an increase in maximum intensities, while introducing the construction effect reduced these values, with models 2 and 4 being the least favorable in terms of displacements.

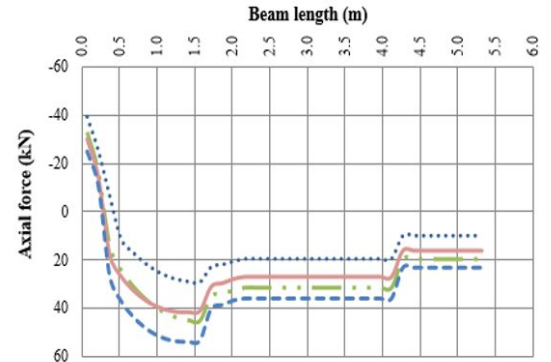

(a)

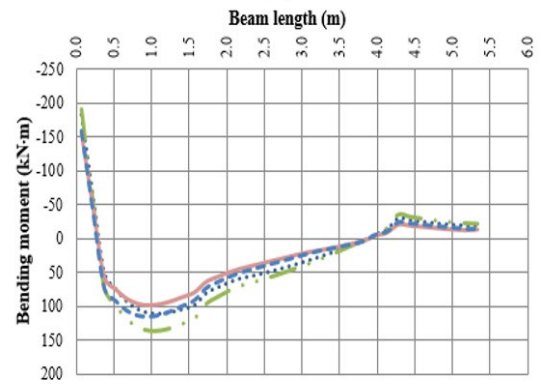

(c)

..... Model 1 - Fixed support

- Model 2 - SSI vert thoriz

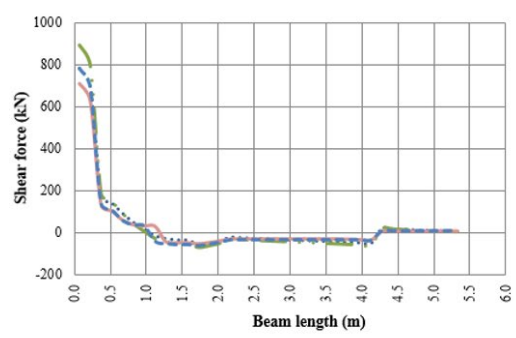

(b)

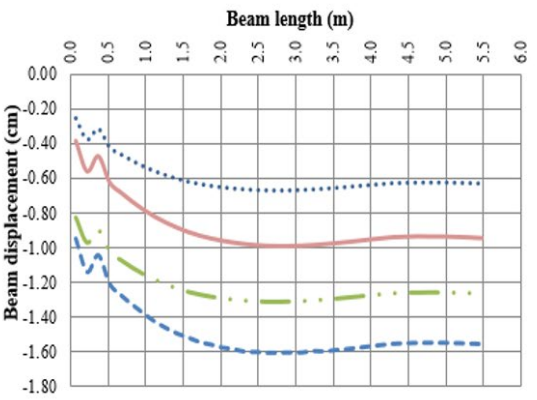

(d)

Model 3 - SC

- - -Model 4 - SSI vert thoriz + SC

Figure 12. Forces on the support beam of wall 45: (a) Axial force; (b) Shear force; (c) Bending moment; (d) Displacements.

Table 9. Maximum forces on the support beam of wall 45.

\begin{tabular}{|c|c|c|c|c|c|c|c|c|}
\hline \multirow[b]{2}{*}{ Model } & \multicolumn{2}{|c|}{ Axial Force (kN) } & \multicolumn{2}{|c|}{ Shear force $(\mathbf{k N})$} & \multicolumn{2}{|c|}{ Bending moment (kN.m) } & \multicolumn{2}{|c|}{ Displacements (cm) } \\
\hline & Maximum & $\begin{array}{c}\Delta \text { fixed } \\
\text { support }\end{array}$ & Maximum & $\begin{array}{c}\Delta \text { fixed } \\
\text { support }\end{array}$ & Maximum & $\begin{array}{c}\Delta \text { fixed } \\
\text { support }\end{array}$ & Maximum & $\begin{array}{c}\Delta \text { fixed } \\
\text { support }\end{array}$ \\
\hline Model 1 & 39.32 & - & 783.13 & - & 183.13 & - & 0.67 & - \\
\hline Model 2 & 45.27 & $15 \%$ & 894.65 & $14 \%$ & 191.87 & $5 \%$ & 1.31 & $96 \%$ \\
\hline Model 3 & 41.50 & $6 \%$ & 708.27 & $-10 \%$ & 155.01 & $-15 \%$ & 0.99 & $48 \%$ \\
\hline Model 4 & 53.72 & $37 \%$ & 780.93 & $-0,3 \%$ & 158.76 & $-13 \%$ & 1.61 & $141 \%$ \\
\hline
\end{tabular}

\subsection{Columns and foundations}

As shown in Figure 13a, the distribution of axial forces between the columns of the building when considering interaction with the soil, and the gradual rise in loading in the structure demonstrate that the smallest differences in relation to model 1 occur in model 3, with a fully-fixed base and only the construction effect. Considering soil deformation in models 2 and 4 causes more pronounced variations, in line with the results illustrated in Figure 13a. Model 4 mitigates the variations of model 2 in relation to 1, that is, promotes a trend to redistribution.

The effects of the SSI in models 2 and 4 demonstrate that corner columns had the largest declines in axial forces in relation to model 1. Columns such as P1, P4, P8, P13, P22, P27, P37, P42, P50, P55, P59 and P62 (Figure 5), exhibited considerable reductions, resulting in an increase in axial forces in the closest columns. 
Figure 13b illustrates the foundation settlements. Geotechnical settlements refer to those in models with a fullyfixed base, calculated using the Cintra and Aoki method. The axial forces in the columns underwent considerable variations after introducing interaction with the soil (models 2 and 4). As such, the settlements also exhibited variations, displaying the expected behavior: reduced settlements in the columns that underwent a decline in axial forces, and an increase in settlements in columns that experienced a rise in these forces. SSI reduced the differential settlements between the elements. It is important to underscore that the settlement values associated with model 1 did not consider the effect of structure stiffness, since they were calculated individually from the support reactions in the columns. In the case of models 3 and 4 , given that soil deformation was simulated by the springs, the corresponding settlements are affected by the stiffness of the structure.

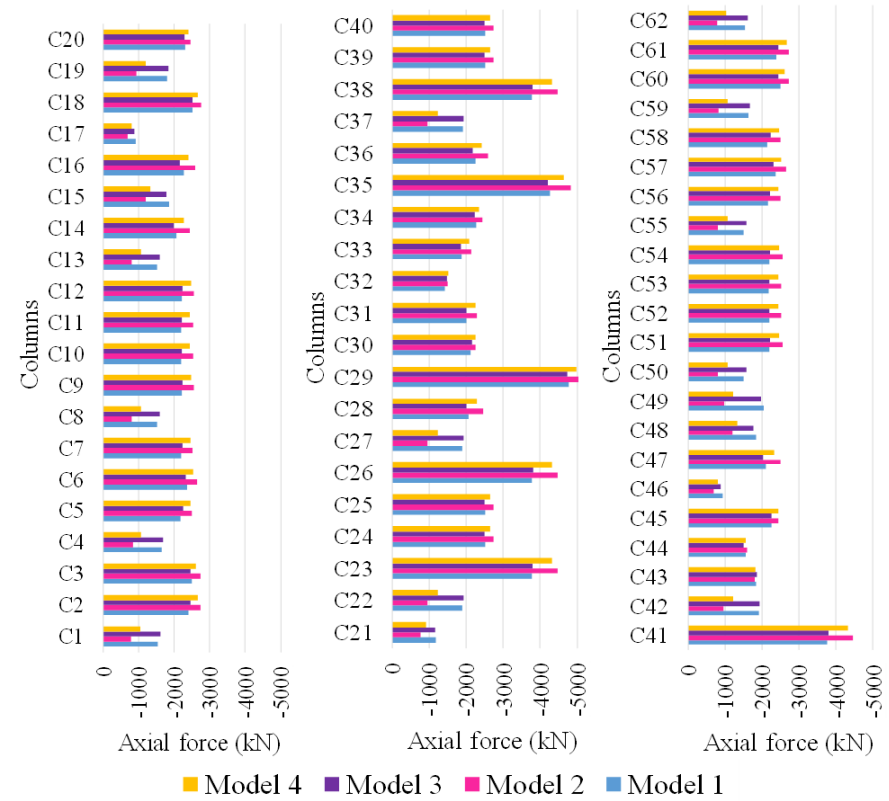

(a)

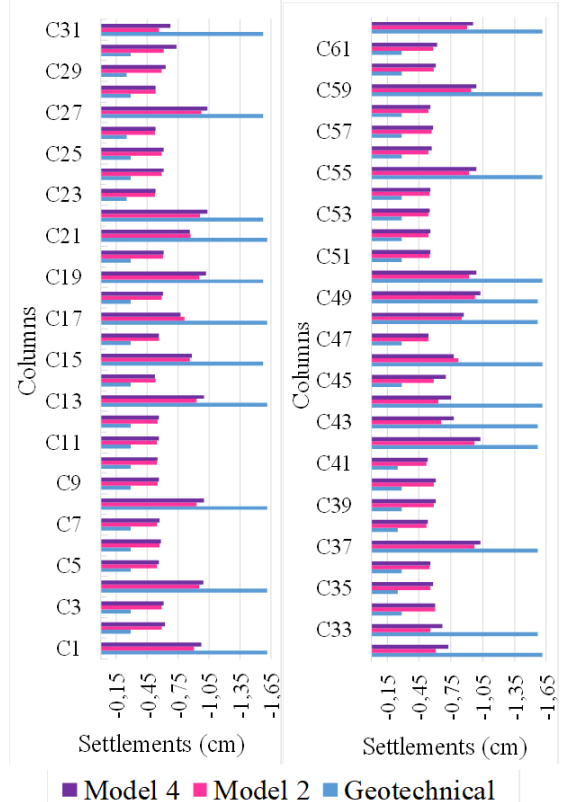

(b)

Figure 13. Columns and foundations results: (a) Maximum axial forces of the columns; (b) Foundation settlements.

\section{CONCLUSIONS}

The results analyzed and discussed here showed important behavior intrinsic to the interaction between masonry structures, as wall-beam systems, and the soil, and loading in the construction stages, as follows:

- In terms of normal and shear stresses at the base of the walls, the behavior observed showed no significant changes. The highest variations occurred in the peak regions, where the model that considers soil-structure interaction and gradual load application was the least favorable, except in the case of one of the walls analyzed, in which the most unfavorable was the model that considers only the SSI. As such, a model that considers interaction with the soil is essential for stress redistribution in the structure. The model that simultaneously considers soil-structure interaction and the effects of construction loads does not correspond to a simple overlap of these effects considered separately. Furthermore, it is important to emphasize that two of the three walls assessed showed variations in stress that do not comply with the safety factor (SF) stipulated by the Brazilian Standard Code, demonstrating the need to include the effects in the structural analysis of buildings similar to that assessed here;

- The forces on the reinforced concrete support beams show more significant differences between the results of the models. Axial force exhibited the greatest differences, demonstrating no behavioral trend. In the case of wall 19, for example, tensile axial force declined when SSI and the construction effect were incorporated, while in wall 41 it increased. A completely different trend occurred in wall 45 , where compressive force declined, and tensile force rose. Akin to the case of stress at the base of the walls, two of the three support beams showed variations in axial force that are not covered by the SF of the Brazilian Standard Code, once again emphasizing the need to include 
soil-structure interaction and the construction effects in the structural analysis of buildings similar to that assessed here;

- By contrast, for all the beams analyzed, shear force and the bending moment increased when only the SSI was considered, and incorporating the construction effect reduced these forces, with the results of the model that considers both effects closely resembling those of the model with fully-fixed column bases.

- As a rule, absolute displacement of the beams in the models that considered interaction with the soil were more than twice as large as those obtained in the model without interaction. In some of the beams analyzed, these absolute displacements exceeded the serviceability limit state established by the Brazilian Standard Code. However, when strain associated with beam supports is disregarded, these limits were fully complied;

- In terms of the axial forces on support structure columns, the models that considered SSI resulted in greater variations in intensities. As expected, the most significant reductions were compensated by increases in this force in nearby columns. These forces variations in the columns caused considerable changes in settlements. Nevertheless, SSI reduced the differential settlements between the elements.

Incorporating SSI and construction effect provoked stress redistribution in the structure, leading to relief in some of the elements and the need for reinforcement increase in others. In conclusion, there is a need to incorporate the construction effects and, especially, soil-structure interaction in the analyses of structural masonry buildings, since these aspects may generate stresses on the walls and forces on the support beams that are not covered by the SF in terms of variations in results as a function of simplifying the model. However, models that use soil discretization in finite elements and other geometric typologies of buildings should be developed to corroborate this critical analysis of the conventionally used design method.

\section{REFERENCES}

[1] Associação Brasileira de Normas Técnicas, Concrete Wall Castes in Place for Building Construction - Requirements and Procedure, NBR 16055, 2012.

[2] Associação Brasileira de Normas Técnicas, Structural Masonry. Part 1: Design, NBR 16868-1, 2020.

[3] E. Testoni, “Análise estrutural de edifícios de paredes de concreto por meio de pórtico tridimensional sobre apoios elásticos,” M.S. thesis, Esc. Eng. São Carlos, Univ. São Paulo, São Carlos, SP, 2013.

[4] P. V. S. Santos, “Ações evolutivas em edifícios de paredes de concreto e de alvenaria, considerando a interação com o solo," M.S. thesis, Esc. Eng. São Carlos, Univ. São Paulo, São Carlos, SP, 2016.

[5] P. C. Barbosa, "Estudo da interação de paredes de alvenaria estrutural com vigas de concreto armado," M.S. thesis, Esc. Eng. de São Carlos, Univ. São Paulo, São Carlos, SP, 2000.

[6] J. A. Nascimento No., K. A. S. Medeiros, and F. Quim, "Nova modelagem para análise da interação entre painéis de alvenaria e estrutura de suporte," Rev. Prisma, no. 52, pp. 39-48, 2014.

[7] K. A. S. Medeiros, "Modelagem computacional para avaliação da interação entre painéis de alvenaria e estrutura de suporte em concreto armado,” M.S. thesis, Prog. Pós-grad. Eng. Civil, Univ. Fed. Rio Grande do Norte, Natal, RN, 2015.

[8] G. A. Parsekian, A. A. Hamid, and R. G. Drysdale, Behavior and Design of Structural Masonry, 2a ed. São Carlos: EDUFSCar, 2013.

[9] A. C. S. Lopes, "Aperfeiçoamento de modelagem computacional para análise da interação entre painéis de alvenaria e estrutura de suporte em concreto armado,” B.S. thesis, Dept. Eng. Civil, Univ. Fed. Rio Grande do Norte, Natal, RN, 2016.

[10] J. A. Nascimento No., "Investigação das solicitações de cisalhamento em edifícios de alvenaria estrutural submetidos a ações horizontais,” M.S. thesis, Esc. Eng. São Carlos, Univ. São Paulo, São Carlos, SP, 1999.

[11] A. D. Gusmão and J. A. Gusmão Fo., “Avaliação da influência da interação solo-estrutura em edificações,” in $X C O B R A M S E F$, Foz do Iguaçu, PR, 1994, pp. 67-74.

[12] J. F. M. A. Prado, "Estruturas de edifícios em concreto armado submetidas a ações de construção,” D.S. dissertation, Esc. Eng. São Carlos, Univ. São Paulo, São Carlos, SP, 1999.

[13] S. C. Dutta and R. Roy, "A critical review on idealization and modeling for interaction among soil-foundation-structure system," Comput. Struc., vol. 80, no. 20-21, pp. 1579-1594, 2002.

[14] M. M. Filonenko-Borodich, "Some approximate theories of elastic foundation," [in Russian] Uch. Zap. Mosk. Gos. Univ. Mekh., vol. 46, pp. 3-18, 1940.

[15] M. Hetenyi, Beams on Elastic Foundations. Ann Arbor: Univ. Michigan Press; 1946.

[16] P. L. Pasternak, On a New Method of Analysis of an Elastic Foundation by Means of Two Foundation Constants [in Russian]. Moscow, USSR: Gosud. Izd. Lit. po Stroi. Arkh., 1954.

[17] A. D. Kerr, "Viscoelastic Winkler foundation with shear interactions," J. Eng. Mech. Div., vol. 87, no. EM3, pp. 13-30, 1961. 
[18] J. S. Horvath, "Beam-column-analogy model for soil-structure interaction analysis," J. Geotech. Eng., vol. 119, no. 2, pp. 358-364, 1993.

[19] N. P. Kurian and N. G. Manojkumar, "A new continuous model for soil-structure interaction," J. Struct. Eng., vol. 27, no. 4, pp. 269$276,2001$.

[20] K. Terzaghi, "Evaluation of coefficients of subgrade reaction," Geotechnique, vol. 5, no. 4, pp. 297-326, 1955.

[21] A. G. D. Araújo, "Provas de carga estática com carregamento lateral em estacas escavadas hélice contínua e cravadas metálicas em areia,” M.S. thesis, Prog. Pós-grad. Eng. Civil, Univ. Fed. Rio Grande do Norte, Natal, RN, 2013.

[22] H. Matlock and L. C. Reese, "Foundation analysis of offshore pile supported structures," in Proc. V Int. Conf. Soil Mech. Found. Eng. ICSMFE, vol. 2, Paris, France, 1961, pp. 91-97.

[23] B. B. Broms, "Lateral resistence of piles in cohesive soils," J. Soil Mech. Found. Div., vol. 90, no. 2, pp. $27-63,1964$.

[24] M. Alizadeh and M. T. Davisson, "Lateral load tests on piles," J. Soil Mech. Found. Div., vol. 96, no. 5, pp. 1583-1604, 1970.

[25] H. G. Poulos, "Behavior of laterally loaded piles: I - single piles," J. Soil Mech. Found. Eng. Div. ASCE, vol. 97, no. 5, pp. 711-731, 1971.

[26] J. C. A. Cintra, "Uma análise de provas de carga lateral em estacas e comparação com os métodos da teoria de reação horizontal do solo,” M.S. thesis, Esc. Eng. São Carlos, Univ. São Paulo, São Carlos, SP, 1981.

[27] M. G. Miguel, "Execução e análise de provas de carga horizontal em estacas em solo colapsível,” M.S. thesis, Esc. Eng. São Carlos, Univ. São Paulo, São Carlos, SP, 1996.

[28] A. Del Pino Jr., "Análise do comportamento de estacas do tipo broca escavada com trado mecânico solicitadas por esforços transversais," M.S. thesis, Fac. Eng. Ilha Solteira, Univ. Est. Paulista, Ilha Solteira, SP, 2003.

[29] C. C. Fan and J. H. Long, "Assessment of existing methods for predicting soil response of the laterally loaded piles in sand," Comput. Geotech., vol. 32, no. 4, pp. 274-289, 2005.

[30] B. B. Zammataro, “Comportamento de estacas tipo escavada e hélice contínua submetidas a esforços horizontais,” M.S. thesis, Fac. Eng. Civ. Arq. Urb., UNICAMP, Campinas, SP, 2007.

[31] A. C. S. Lopes, “Avaliação do comportamento de edifícios de alvenaria estrutural sobre estrutura de transição considerando a interação solo-estrutura e o efeito construtivo,” M.S. thesis, Prog. Pós-grad. Eng. Civil, Univ. Fed. Rio Grande do Norte, Natal, RN, 2019.

[32] Associação Brasileira de Normas Técnicas, Concrete Structures Design - Procedure, NBR 6118, 2014.

[33] G. A. Parsekian and L. S. Franco, "Time-dependent strength and creep in masonry," TMS J., vol. 24, no. 1, pp. 83-94, 2006.

[34] Associação Brasileira de Normas Técnicas, Building Construction - Bases for design of structures - Wind Loads - Procedure, NBR 6123, 1988.

[35] J. C. A. Cintra and N. Aoki, Fundações por Estacas: Projeto Geotécnico, 1a ed. São Paulo: Oficina de Textos, 2010.

[36] N. Aoki and D. A. Velloso, “An approximate method to estimate the bearing capacity of piles," in Vth Pan Am. Conf. Soil Mech. Found. Eng., vol. 1, Buenos Aires, 1975, pp. 367-376.

[37] L. Décourt, "Load-deflection prediction for laterally loaded piles based on N-SPT values," in Proc. 4 Int. Conf. Piling and Deep Found., vol. 1, 1991, pp. 549-555.

[38] J. Blévot and R. Frémy, "Semelles sur pieux," Analles L'Institut Tech. Batiment Trav. Publics Paris, vol. 20, no. 230, pp. 223-295, 1967.

[39] Associação Brasileira de Normas Técnicas, Actions and Safety of Structures - Procedure, NBR 8681, 2004.

Author contributions: ACSL: development of the primary research and writing the manuscript; JANN: supervision of the primary research, results discussions and manuscript review; RB: contributions to the primary research, results discussions and manuscript review.

Editors: Fernando Soares Fonseca, Guilherme Aris Parsekian. 